\title{
CSABA PLÉH \\ LOOKING FOR GOD IN THE BRAIN: A CHALLENGING TASK
}

\author{
BEAUREgaRd, M. \& D. O'LeARY (2007) The Spiritual Brain: A Neuroscientist's \\ Case for the Existence of the Soul (New York: HarperOne) 368 pp., \\ ISBN 9780060858834, \$ 25.95.
}

The book written by a professional neuroscientist (BEAUREGARD \& PAQUETTE 2006) and a professional science writer aims to be a balanced overview against the naturalization of the mind, seemingly so popular in present day science, psychology, and even philosophy. The authors (both Canadian) have certainly made a welcome contribution. They have surveyed all the mock science and pseudoscience that claim to reveal "God centers" in the brain, and the truth about the essence of spiritual experiences.

During the last decade, serious synthetic efforts have been made on the part of philosophers or philosophically minded natural scientists to show how notions like God that are so crucial for cultural integration are in fact merely illusions or ad hoc interpretations of our experiences. Or, on the other hand, they may have an important bio-social function by integrating communities and giving a scaffolding for personal identity; at the same time they are mere fancies of the mind. The authors rather carefully show all the cultural reception of the recent works of DAWKINS (2006) and DENNETT (2006), and sarcastically present that their books had a negative response both in spiritualist and in naturalist circles. They also rightfully point out that both authors lack their wit and any depth of conceptual analysis: they have fallen into the trap of pop writing about pop topics.

So far, so good. However, most unfortunately, Beauregard and O'Leary fall into the same trap. They are good at exposing serious challenges to the naturalist, they even plainly tell the materialist vision of the world and the mind. They, however, fail to expose a sound vision of the dualist attitudes they seem to be defending.

The book as a whole wants to point out the scientific inconsistencies and weak support for the intentionally naturalistic claims about God in the brain. They provide fun reading about the "God Helmet" and similar sensationalistic pieces of research. They make a strong case to remind scientists and their popularizers to stay more selfcritical and sober. However, when they come to conclusions against the materialists, they seem to be easily accepting the intervention of spiritual factors. Their wit and irony leave them when they want to believe that there's more to the mind than just the brain.

I do not intend to be dogmatic here, and question their commitment in the name of a monist-materialist view of the world and the mind. However, the scepticism and irony brought in by modern science should be a serious attitudinal help here. It is rather telling and interesting that the relatively early work of DANIEL DENNETT $(1991,1994)$ misses their perspective. That is where Dennett proposed a rather intricate narrative 
theory of self and consciousness, intending to overcome the tensions of localizationist materialism and the trivialities of our feeling of self-integration. It is also rather telling that the book entirely misses new materialist-spiritualist debates like the books of Changeux and Ricoeur (CHANGEUX 2002; CHANGEUX \& RiCOEUR 2000).

Another critical miss in the book is the total lack of considering the functionalist tradition in dealing with the mind-brain relation. The Aristotelian, rather than the Cartesian, position was clearly modernized by Gilbert RYLE (1949), and then spread into the functionalist attitude of cognitive science (see the reader edited by BLOCK 1980). This attitude, as some examples like the Hungarian SCHILLER (1947) showed, allows one to avoid the simply localizationist attitude of both parties in the present "spiritualist-materialist" debate as presented by the authors. (See PLÉH 2009 about this attitude.)

While it seems to give in to the pop style, in many respects the book remains difficult to read. It has a difficult organization. The reader has to check all materials in two places: in a short reference list, and in the footnotes, the latter ones being hard to follow due to their numbering. This challenging task emulates the dual aims of the book: to be a serious defence of dualism, and a pop anti-naturalist pamphlet.

In sum, the book is a welcome reading for believers, supporting their commitment towards claiming the existence of a spiritual domain, and at the same time it is more of a half-serious reading for the ignorant and the atheist. It does not provide a convincing synthesis of the spiritualist claims. Rather, it gives an ironical picture of the fallacies in the argumentation of both the naturalists and the believers. There is still more to come.

\section{References}

Beauregard, M. \& V. Paquette (2006) 'Neural Correlates of a Mystical Experience in Carmelite Nuns', Neuroscience Letters 405, 186-190.

Block, N. (1980) Readings in the Philosophy of Psychology (Cambridge: Harvard University Press).

ChangeuX, J. P. (2002) The Physiology of Truth: Neuroscience and Human Knowledge (Cambridge: Harvard University Press).

ChangeuX, J. P. \& P. Ricoeur (2000) What Makes Us Think? A Neuroscientist and a Philosopher Argue about Ethics, Human Nature, and the Brain (Princeton: Princeton University Press).

Dawkins, R. (2006) The God Delusion (Boston: Houghton Mifflin).

DENNETT, D. (1991) Consciousness Explained (Boston: Little Brown).

DenNetT, D. (1994) Darwin's Dangerous Idea (New York: Simon and Schuster).

DennetT, D. (2006) Breaking the Spell: Religion as a Natural Phenomenon (New York: Viking).

PLÉH, CS. (2009) History and Theories of the Mind (Budapest: Akadémiai).

RYLE, G. (1949) The Concept of Mind (London: Hutchinson).

SCHILlER, P. H. (1947) Die Aufgabe der Psychologie (Wien: Springer). 